\title{
An Analysis of Oil Price Volatility Using VAR: Evidence From Pakistan
}

\section{Abdul Rafay* and Saqib Farid ${ }^{* *}$}

\begin{abstract}
Oil is a crucial economic input and Pakistan's growth, production levels, and price levels are affected significantly by oil price volatility. This paper captures the impact of oil price shocks on Pakistan's economy by considering variables such as gross domestic product, the wholesale price index, and largescale manufacturing index. Our analysis is based on vector autoregression and the results are in line with similar studies. We also determine the precise shortterm or long-term impact of oil price volatility on the relevant variables.
\end{abstract}

Keywords: vector autoregression, gross domestic product, wholesale price index, large scale manufacturing index, oil price volatility.

JEL classification: E30, E31, E32.

\section{Introduction}

Oil plays a key role in the development of an economy. As a result of recent shifts in the world energy market, the effects of oil price volatility may have a weaker impact on the economy. In the developed world, the impact of such variations is reduced when economies evolve from being strictly dependent on oil-intensive energy sources to other, more efficient, energy sources. This helps reduce the adverse effects of oil price changes and protects the economy from undesirable shocks.

High oil price volatility has been a long-term feature of the international oil market, where price volatility is not only due to the shortterm disequilibrium of supply and demand, but is also associated with political and behavioral factors beyond the scope of this analysis. This is confirmed by the fact that both oil supply and demand have remained more consistent than price levels in the international economy. Where the developed world has managed to mitigate the effect of such shocks on the

\footnotetext{
* Associate professor of finance and accounting, University of Management and Technology, Lahore.

** MS scholar, University of Management and Technology, Lahore.
} 
economy, nonproducing developing, and underdeveloped countries are still subject to the impact of such fluctuations (Aparna, 2013).

Oil price volatility increases the cost of energy manufacturing; these increased costs trickle down to other sectors and levels of the economy. The net import of oil results in a considerable net outflow of foreign reserves. This affects the economy in the form of adverse exchange rate movements, declining currency values, falling exports and a weaker trade balance. A considerable fall in the current account also affects the treasury budget negatively, reducing tax revenues and other factors (Bhattacharya \& Bhattacharya, 2001; Aparna, 2013).

The impact of oil price shocks can vary from country to country, depending on various macroeconomic factors. Assessing this impact is particularly important in the case of developing economies such as Pakistan, given the recent decrease in oil prices and ensuing shocks to the economy. Pakistan is an oil-intensive economy and the dependence of both its industry and household productivity and use is linked strongly to international prices. The disparity between production levels and needs is very large. Oil imports constitute 36 percent of Pakistan's total import bill. The International Monetary Fund estimates the value of Pakistan's oil imports at US\$ 13.631 billion in 2013. This puts it at number 34 in world rankings for the value of oil imports, where the world's average value of oil imports is US $\$ 14.94$ billion. ${ }^{1}$

This pattern of increasing imports is expected to continue, given that no major oil reserves have been discovered while the demand for oil keeps rising. Additionally, there is a substantial disparity between oil production and consumption. The average value of oil production for Pakistan was 52.93 thousand barrels per day with a minimum of 11.2 thousand barrels per day in 1980 and a maximum of 69.26 thousand barrels per day in 2006. This ranks Pakistan at 54 in terms of world oil production.

As Pakistan is a large importer of crude oil, oil price volatility tends to affect most sectors, from energy production and food and agriculture to manufacturing and transportation. This study attempts to capture the impact of oil price changes on Pakistan's economy. The variables selected are based on the literature and optimally explain the impact of oil price volatility on different areas and participants of the economy. GDP and the large-scale manufacturing index (LSMI) are used

\footnotetext{
${ }^{1}$ The value is equal to the price per unit of the quantity of oil imports multiplied by the number of units.
} 
to measure the impact of a change in oil prices on economic growth and production. The wholesale price index (WPI) estimates the impact on the price level in the economy.

The study adds value to the literature because it uses a vector autoregression (VAR) model to investigate the impact of oil prices on Pakistan's economy.

\section{Literature Review}

Empirical studies on oil prices go back to the mid-1970s when the supply embargo by OPEC suddenly pushed up oil prices, triggering a global recession. Earlier studies, such as Rasche and Tatom $(1977,1981)$, Derby (1982), and Gisser and Goodwin (1986), did not determine the causal relationship between the recession and preceding oil price hikes, but pointed out the negative relationship between oil price increments and real GDP.

Hamilton (1983, 1985, 1996), using a series of VAR models, determines that, after the Second World War, almost all the recessions in the US economy were preceded by oil price increments that had a positive impact on wages and the general price level. Burbidge and Harrison (1984) add another dimension to the literature by concluding that the impact of changes in oil prices on these macroeconomic variables differs by country, even among developed economies.

The choice of variables used to assess the impact of oil price volatility also differs. Ito (2010) investigates the impact of oil price shocks on the Russian economy and exchange rate, using a VAR model to capture the relationship. The empirical results indicate that an increase in oil prices causes depreciation in the exchange rate and GDP, but the impact of such a shock results in a marginal positive increment in general prices.

Dias (2013) investigates the impact of oil prices on the Portuguese economy in terms of GDP, employment, and inflation. His empirical analysis relies on a VAR model and yields similar results to the studies cited above: oil price changes have a negative relationship with GDP and employment, but a positive impact on inflation. Saghaian (2010) looks at the impact of oil prices on commodity prices to determine whether the variables have a causal relationship or are just strongly correlated. The results are mixed: the findings confirm a strong correlation between oil prices and commodity prices, but no conclusive evidence of a causal relationship. 
Some studies yield similar findings for different regions of the world. Berument, Ceylan, and Dogan (2010) investigate the impact of oil price shocks on the MENA countries (excluding Saudi Arabia) in terms of output. They use a VAR model to analyze the impact of oil prices; the results of the impulse analysis show that oil prices have a positive impact on the economy in all the countries studied, barring a few for which the results are not statistically significant. Papapetrou (2001) assesses the impact of oil price changes on the Greek economy, using a regime switch model and threshold regression model. She finds a high negative correlation between oil prices and economic activity in the presence of high oil price volatility.

A cross-country analysis by Cologni and Manera (2008) analyzes the impact of oil prices on the G-7 countries, using a co-integrated VAR model. The study focuses on the impact of oil price shocks on output, the general price level, and Monterrey variables. The results show that unexpected oil price changes affect the interest rate, where governments have tried to counter inflation through contradictory monetary policy responses. The rise in the interest rate, pushed up by oil price shocks, is transmitted to the real economy, reducing output and inflation. Other studies have tried to deepen their analyses by determining the nonlinear relationship between oil prices and different macroeconomic variables (see Lee, Ni, \& Ratti, 1995; Hamilton, 2003, 2011) and by capturing the asymmetric impact of oil price volatility (see Hooker, 2002).

This study is similar to Aparna (2013) in that we consider the effect of oil prices on the WPI, GDP and industrial production index, which serve as proxies for prices, growth, and production, respectively. Since no direct causal relationship is established between the variables, we employ a VAR model. The results confirm that a positive change in oil prices has a positive effect on the WPI and an immediate negative impact on GDP and production. Our findings also confirm that, when the oil price shock enters the system, it takes around ten quarters in the case of GDP and industrial production to return to their original values; the WPI returns to its original value immediately.

\section{Data and Methodology}

This section describes the data and method used to assess the impact of oil price volatility in Pakistan. 


\subsection{Data}

We use annual data for the period 1982/83 to 2012/13. Annual GDP is measured over June to May of the financial year. The data is taken from the State Bank of Pakistan's Research Bulletin for 2013. The crude oil (petroleum) price is a simple average of three spot prices - the Dated Brent, the West Texas Intermediate, and the Dubai Fateh - and is given in PRs per barrel as an annual average.

The data on the WPI is taken from the Pakistan Bureau of Statistics. The index is designed to measure the direction of prices of selected items in wholesale primary markets. The dataset covers 21 city markets and its basket of goods includes 463 items divided into five categories. The base year is 2004/05 and the index is calculated according to the Laspeyres formula.

The manufacturing index is divided into the small industries index and the LSMI. We use the latter because it includes those sectors that are most affected by oil price volatility and which account for a major share of the country's exports and current account balance. The Census of Manufacturing Industries was used to develop new weights for the quantum index of manufacturing. The base year of the data is $1980 / 81$ and 106 items were used to calculate the indices.

\subsection{Unit Root Tests for Variables}

Given that the data series is not stationary and the log of normal values is considered, we cannot determine a causal relationship between the variables using the standard t-test and F-test. In this situation, employing a VAR model helps analyze dynamic macroeconomic timeseries data. The augmented Dickey-Fuller test is applied to each variable to determine the presence of a unit root (Tables A1 to A4 in the Appendix).

\subsection{Econometric Model and Hypothesis}

It can be difficult to interpret the coefficients obtained from a VAR model and use it to make predictions - the model is, nonetheless, useful for studying business cycles and the economic impact of oil price shocks because it enables us to draw policy recommendations from the results obtained. Each variable is considered endogenous and estimated using past values of the dependent variable and other variables in the model. Next, we calculate the coefficients to forecast estimates. To do so, we must select the number of lagged terms, as including too many lags can 
lead to multicollinearity and the loss of useful observations. Accordingly, we restrict the number of lagged terms to two periods. The econometric model is given below:

$$
\begin{aligned}
& Y_{t}=\alpha+\beta_{\gamma t-1}+\beta_{\gamma t-2}+\cdots \beta_{k} Y_{m-K}+\varepsilon_{t} \\
& Y_{t}=\left(Y_{1 t}, Y_{2 t} \ldots Y_{m t}\right) \\
& \beta=(i=1,2 \ldots K)
\end{aligned}
$$

where, in equation (2), the time series vector is $n \times 1$ and in equation (3), the coefficient matrices are $n \times n$.

Our proposed hypothesis is that there is a significant relationship between oil price changes, GDP, the LSMI, and the WPI.

\section{Results}

Table 1 gives the estimates yielded by the VAR model.

Table 1: VAR estimates

\begin{tabular}{lllll}
\hline & \multicolumn{1}{c}{ WPI03 } & \multicolumn{1}{c}{ GDP02 } & \multicolumn{1}{c}{ LSMI01 } & \multicolumn{1}{c}{ OIL01 } \\
\hline WPI03(-1) & -1.228023 & -11724.41 & 0.212450 & 5.512445 \\
& $(0.30444)$ & $(13897.6)$ & $(0.25861)$ & $(13.2384)$ \\
WPI03(-2) & {$[-4.03367]$} & {$[-0.84363]$} & {$[0.82150]$} & {$[0.41640]$} \\
& -0.756428 & 30643.87 & 0.314730 & -45.15665 \\
& $(0.48128)$ & $(21970.1)$ & $(0.40883)$ & $(20.9281)$ \\
GDP02(-1) & {$[-1.57170]$} & {$[1.39480]$} & {$[0.76983]$} & {$[-2.15771]$} \\
& $1.81 \mathrm{E}-05$ & 0.010406 & $4.63 \mathrm{E}-05$ & 0.000373 \\
& $(1.8 \mathrm{E}-05)$ & $(0.80049)$ & $(1.5 \mathrm{E}-05)$ & $(0.00076)$ \\
GDP02(-2) & {$[1.03124]$} & {$[0.01300]$} & {$[3.10971]$} & {$[0.48961]$} \\
& $-8.85 \mathrm{E}-06$ & 1.345508 & $-1.09 \mathrm{E}-05$ & -0.000366 \\
LSMI01(-1) & $(7.2 \mathrm{E}-06)$ & $(0.33019)$ & $(6.1 \mathrm{E}-06)$ & $(0.00031)$ \\
& {$[-1.22414]$} & {$[4.07498]$} & {$[-1.77831]$} & {$[-1.16419]$} \\
& 0.294378 & 14558.74 & 0.209111 & 1.296470 \\
LSMI01(-2) & $(0.24075)$ & $(10990.2)$ & $(0.20451)$ & $(10.4689)$ \\
& {$[1.22273]$} & {$[1.32470]$} & {$[1.02249]$} & {$[0.12384]$} \\
& -0.481174 & 11956.75 & -0.666070 & 2.823203 \\
OIL01(-1) & $(0.36688)$ & $(16748.0)$ & $(0.31166)$ & $(15.9536)$ \\
\hline
\end{tabular}




\begin{tabular}{lllll}
\hline & WPI03 & GDP02 & LSMI01 & OIL01 \\
\hline & $(0.00633)$ & $(288.979)$ & $(0.00538)$ & $(0.27527)$ \\
OIL01(-2) & {$[1.64906]$} & {$[-2.44976]$} & {$[2.31457]$} & {$[3.70128]$} \\
& -0.014871 & 212.7948 & -0.024373 & -0.099205 \\
& $(0.00850)$ & $(388.238)$ & $(0.00722)$ & $(0.36982)$ \\
C & {$[-1.74857]$} & {$[0.54810]$} & {$[-3.37360]$} & {$[-0.26825]$} \\
& 1.444532 & -215858.7 & 12.98092 & 32.60077 \\
& $(4.05356)$ & $(185041)$. & $(3.44336)$ & $(176.265)$ \\
R squared & {$[0.35636]$} & {$[-1.16654]$} & {$[3.76985]$} & {$[0.18495]$} \\
Adj. R squared & & & & \\
Sum of squared residuals & 1220.413 & 2.540000 & 880.6385 & 2307632. \\
SE equation & 0.762450 & 0.728000 & 0.534473 & 0.775581 \\
F-statistic & 0.656872 & 0.607111 & 0.327573 & 0.675839 \\
Log likelihood & 7.221679 & 375880.2 & 6.994595 & 358.0527 \\
Akaike info criterion & -8.022065 & 2.583236 & 7.775890 \\
Schwarz criterion & 7.315652 & 28.77313 & 6.989354 & 14.86044 \\
Mean dependent & 7.747597 & 29.20508 & 7.421300 & 15.29238 \\
SD dependent & -0.018148 & -2217.370 & 9.430000 & 333.4638 \\
& 14.05688 & 599673.4 & 8.529821 & 628.8786 \\
Determinant residual covariance (df adj.) & 1.690000 & & \\
Determinant residual covariance & 3.340000 & & \\
Log likelihood & & -729.0659 & & \\
AIC & & 56.67155 & & \\
SC & 58.39933 & & \\
\hline
\end{tabular}

Source: Authors' calculations.

The Akaike and Schwarz statistics indicate the goodness of fit and help determine the number of lagged terms: the lower the critical values, the better will be the model fit. The value of both statistics in our model seems very high, but this criterion is not absolute since the statistics only make sense when compared to another model with a slight variation in the explanatory variables. The f-statistic is not very high, which allows us to reasonably assert that, collectively, all the terms are statistically significant.

The model for the first lag shows that a one-percent increase leads the WPI to rise 5.51224 times. This confirms that an increase in oil prices leads to an increase in the general wholesale price of the commodities included in the basket. In the second-lag model, the prices go down as the lagged value of the WPI also falls. 
A one-percent increase in the value of the LSMI is associated with a positive impact on the price of oil (by 0.012447 times). In the second lag, the LSMI decreases with a negative impact on oil prices. This confirms that oil prices have a negative impact on the quantum index of large-scale industries and thus on production. As prices go down, the system recovers. Finally, a one-percent increase in oil prices leads to a $0.000373-$ time increase in GDP in the first lag. As oil prices fall slightly in the second lag, so does GDP.

\section{Conclusion}

The study provides important insights into the impact of oil price shocks on the economy. We find that the economic system has a memory and that price volatility has a negative impact on GDP and the LSMI, and a positive relationship with the WPI. Price volatility has a greater shortterm impact than a long-term impact on GDP and the WPI - a one-year period in this case (one-period lagged value). In the case of the LSMI, the impact of price volatility is more severe in the long term (two-period lagged values).

This empirical analysis allows us to predict the long-term relationship between the relevant variables. However, one limitation of the study is that the available data is annual (from 1982 to 2013). Future studies could use quarterly data to obtain a more precise short-term impact of oil price shocks on these variables. 


\section{References}

Aparna, A. (2013). Impact of oil prices on the Indian economy. NMIMS Management Review, 23(9-10), 141-147.

Berument, M. H., Ceylan, N. B., \& Dogan, N. (2010). The impact of oil price shocks on the economic growth of selected MENA countries. The Energy Journal, 31(1), 149-173.

Bhattacharya, K., \& Bhattacharya, I. (2001). Impact of increase in oil prices on inflation and output in India. Economic and Political Weekly, 36(51), 4735-4741.

Burbidge, J., \& Harrison, A. (1984). Testing for the effects of oil-price rises using vector autoregressions. International Economic Review, 25(2), $459-484$.

Cologni, A., \& Manera, M. (2008). Oil prices, inflation and interest rates in a structural co-integrated VAR model for the G-7 countries. Energy Economics, 30(3), 856-888.

Derby, M. R. (1982). The price of oil and world inflation and recession. American Economic Review, 72(4), 738-751.

Dias, F. C. (2013). Oil price shocks and their effects on economic activity and prices: An application for Portugal. Economic Bulletin, 19(2), $39-48$.

Gisser, M., \& Goodwin, T. H. (1986). Crude oil and the macroeconomy: Tests of some popular notions: Note. Journal of Money, Credit and Banking, 18(1), 95-103.

Hamilton, J. D. (1983). Oil and the macroeconomy since World War II. Journal of Political Economy, 91(2), 228-248.

Hamilton, J. D. (1985). Historical causes of postwar oil shocks and recessions. The Energy Journal, 6(1), 97-116.

Hamilton, J. D. (1996). This is what happened to the oil pricemacroeconomy relationship. Journal of Monetary Economics, 38(2), 215-220. 
Hamilton, J. D. (2003). What is an oil shock? Journal of Econometrics, 113(2), 363-398.

Hamilton, J. D. (2011). Nonlinearities and the macroeconomic effects of oil prices. Macroeconomic Dynamics, 15, 364-378.

Hooker, M. A. (2002). Are oil shocks inflationary? Asymmetric and nonlinear specifications versus changes in regime. Journal of Money, Credit and Banking, 34(2), 540-561.

Ito, K. (2010). The impact of oil price volatility on macroeconomic activity in Russia. Economic Analysis Working Papers, 9(5), 1-21.

Lee, K., Ni, S., \& Ratti, R. (1995). Oil shocks and the macroeconomy: The role of price variability. The Energy Journal, 16(4), 39-56.

Papapetrou, E. (2001). Oil price shocks, stock market, economic activity and employment in Greece. Energy Economics, 23(5), 511-532.

Saghaian, S. H. (2010). The impact of the oil sector on commodity prices: Correlation or causation? Journal of Agricultural and Applied Economics, 42(3), 477-485.

Rasche, R. H., \& Tatom, J. A. (1977). Energy resources and potential GNP. Federal Reserve Bank of St Louis Review, 59(6), 10-24.

Rasche, R. H., \& Tatom, J. A. (1981). Energy price shocks, aggregate supply, and monetary policy: The theory and international evidence. Carnegie-Rochester Conference Series on Public Policy, 14, 9-93. 


\section{Appendix}

Table A1: Unit root test for GDP

\begin{tabular}{lrrr}
\hline & Level & t-statistic & Prob. $^{*}$ \\
\hline ADF test statistic & & -3.227406 & 0.0307 \\
Test critical values & $1 \%$ & -3.737853 & \\
& $5 \%$ & -2.991878 & \\
& $10 \%$ & -2.635542 & \\
\hline
\end{tabular}

* MacKinnon (1996) one-sided p-values.

\section{Augmented Dickey-Fuller test equation}

Dependent variable: D (GDP02)

Method: least squares

Sample (adjusted): 730

Included observations: 24 after adjustments

\begin{tabular}{lllll}
\hline Variable & Coefficient & \multicolumn{1}{c}{ SE } & t-statistic & Prob. \\
\hline GDP02 (-1) & -2.808913 & 0.870332 & -3.227406 & 0.0049 \\
D (GDP02 (-1)) & 1.572182 & 0.886542 & 1.773388 & 0.0941 \\
D (GDP02 (-2)) & 2.400686 & 0.966130 & 2.484846 & 0.0237 \\
D (GDP02 (-3)) & 3.334365 & 1.081073 & 3.084311 & 0.0067 \\
D (GDP02 (-4)) & 3.664758 & 0.857800 & 4.272274 & 0.0005 \\
D (GDP02 (-5)) & 2.601091 & 1.000785 & 2.599051 & 0.0187 \\
C & 85144.69 & 115412.6 & 0.737742 & 0.4707 \\
& & & & \\
R squared & 0.826555 & Mean dependent VAR & -90139.63 \\
Adjusted R squared & 0.765339 & SD dependent VAR & 872987.7 \\
SE of regression & 422891.5 & Akaike info criterion & 28.98611 \\
Sum squared residuals & $3.04 \mathrm{E}+12$ & Schwarz criterion & 29.32971 \\
Log likelihood & -340.8333 & Hannan-Quinn criterion & 29.07727 \\
F-statistic & 13.50226 & Durbin-Watson statistic & 2.287981 \\
Prob. (F-statistic) & 0.000012 & & \\
\hline
\end{tabular}

Source: Authors' calculations. 
Table A2: Unit root test for LSMI

\begin{tabular}{lccc}
\hline & Level & t-statistic & Prob. $^{*}$ \\
\hline ADF test statistic & & -4.646364 & 0.0009 \\
Test critical values & $1 \%$ & -3.679322 & \\
& $5 \%$ & -2.967767 & \\
& $10 \%$ & -2.622989 & \\
\hline
\end{tabular}

* MacKinnon (1996) one-sided p-values.

\section{Augmented Dickey-Fuller test equation}

Dependent variable: D (LSMI01)

Method: least squares

Sample (adjusted): 331

Included observations: 29 after adjustments

\begin{tabular}{lllll}
\hline Variable & Coefficient & \multicolumn{1}{c}{ SE } & t-statistic & Prob. \\
\hline LSMI01 (-1) & -0.910949 & 0.196056 & -4.646364 & 0.0001 \\
C & 8.301612 & 2.440958 & 3.400964 & 0.0021 \\
& & & & \\
R squared & 0.444315 & Mean dependent VAR & -0.327586 \\
Adjusted R squared & 0.423734 & SD dependent VAR & 11.23692 \\
SE of regression & 8.530193 & Akaike info criterion & 7.191573 \\
Sum squared residuals & 1964.633 & Schwarz criterion & 7.285869 \\
Log likelihood & -102.2778 & Hannan-Quinn criterion & 7.221105 \\
F-statistic & 21.58870 & Durbin-Watson statistic & 1.968124 \\
Prob. (F-statistic) & 0.000079 & & \\
\hline
\end{tabular}

Source: Authors' calculations. 
Table A3: Unit root test for oil prices

\begin{tabular}{lccc}
\hline & Level & t-statistic & Prob. $^{*}$ \\
\hline ADF test statistic & & -4.596441 & 0.0010 \\
Test critical values & $1 \%$ & -3.679322 & \\
& $5 \%$ & -2.967767 & \\
& $10 \%$ & -2.622989 & \\
\hline
\end{tabular}

* MacKinnon (1996) one-sided p-values.

\section{Augmented Dickey-Fuller test equation}

Dependent variable: D (OIL01)

Method: least squares

Sample (adjusted): 331

Included observations: 29 after adjustments

\begin{tabular}{llllc}
\hline Variable & Coefficient & \multicolumn{1}{c}{ SE } & t-statistic & Prob. \\
\hline OIL01 (-1) & -0.872975 & 0.189924 & -4.596441 & 0.0001 \\
C & 284.7148 & 128.5491 & 2.214832 & 0.0354 \\
& & & & \\
R squared & 0.438987 & Mean dependent VAR & 13.55107 \\
Adjusted R squared & 0.418209 & SD dependent VAR & 806.3624 \\
SE of regression & 615.0546 & Akaike info criterion & 15.74777 \\
Sum squared residuals & 10213889 & Schwarz criterion & 15.84207 \\
Log likelihood & -226.3427 & Hannan-Quinn criterion & 15.77730 \\
F-statistic & 21.12727 & Durbin-Watson statistic & 2.076925 \\
Prob. (F-statistic) & 0.000090 & & \\
\hline
\end{tabular}

Source: Authors' calculations. 
Table A4: Unit root test for WIP

\begin{tabular}{lrrr}
\hline & Level & t-statistic & Prob. $^{*}$ \\
\hline ADF test statistic & & -9.780636 & 0.0000 \\
Test critical values & $1 \%$ & -3.689194 & \\
& $5 \%$ & -2.971853 & \\
& $10 \%$ & -2.625121 & \\
\hline
\end{tabular}

* MacKinnon (1996) one-sided p-values.

\section{Augmented Dickey-Fuller test equation}

Dependent variable: D (WPI03)

Method: least squares

Sample (adjusted): 330

Included observations: 28 after adjustments

\begin{tabular}{lllll}
\hline Variable & Coefficient & \multicolumn{1}{c}{ SE } & t-statistic & Prob. \\
\hline WPI03 (-1) & -2.742005 & 0.280350 & -9.780636 & 0.0000 \\
D (WPI03 (-1)) & 0.641060 & 0.153353 & 4.180280 & 0.0003 \\
C & -0.017886 & 1.541214 & -0.011605 & 0.9908 \\
& & & & \\
R squared & 0.903156 & Mean dependent VAR & -0.011786 \\
Adjusted R squared & 0.895409 & SD dependent VAR & 25.21691 \\
SE of regression & 8.155299 & Akaike info criterion & 7.136170 \\
Sum squared residuals & 1662.723 & Schwarz criterion & 7.278906 \\
Log likelihood & -96.90638 & Hannan-Quinn criterion & 7.179806 \\
F-statistic & 116.5737 & Durbin-Watson statistic & 2.323617 \\
Prob. (F-statistic) & 0.000000 & & & \\
\hline
\end{tabular}

Source: Authors' calculations. 